\title{
A long-term response to allogeneic hemo- poietic stem cell transplantation from haploidentical donor and post-transplant therapy in an adolescent with primary resistant neuroblastoma
}

Ilya V. Kazantsev ${ }^{1}$, Tatiana V. Iukhta ${ }^{1}$, Asmik G. Gevorgian ${ }^{1}$, Polina S. Tolkunova ${ }^{1}$, Andrew V. Shamin ${ }^{2}$, Vadim V. Baykov ${ }^{3}$, Nikolay A. Vorobyov ${ }^{4}$, Andrew V. Kozlov ${ }^{1}$, Marina A. Karsakova ${ }^{2}$, Polina S. Kuga ${ }^{1}$, Alexander N. Shvetsov ${ }^{1}$, Elena V. Morozova ${ }^{1}$, Svetlana S. Safonova ${ }^{1}$, Yuri A. Punanov ${ }^{1}$, Ludmila S. Zubarovskaya ${ }^{1}$, Boris V. Afanasyev 1

${ }^{1}$ RM Gorbacheva Research Institute of Pediatric Oncology, Hematology and Transplantation, Pavlov University, St. Petersburg, Russia

${ }^{2}$ N. N. Ivanova Samara Regional Pediatric Hospital, Samara, Russia

${ }^{3}$ Chair of Pathology, Pavlov University, St. Petersburg, Russia

${ }^{4}$ Dr. Berezin Medical Institute, St. Petersburg, Russia; I. Mechnikov North-Western State Medical University; Saint Petersburg State University, St. Petersburg, Russia

${ }^{5}$ Department and Chair of Roentgenology, Pavlov University, St. Petersburg, Russia

\section{Dr. Ilya V. Kazantsev, RM Gorbacheva Research Institute of} Pediatric Oncology, Hematology and Transplantation, Pavlov University, L. Tolstoy St. 6-8, 197022, St. Petersburg, Russia
Phone: +7 (963) 3480524

E-mail: Ilya_Kazantsev@inbox.ru

Citation: Kazantsev IV, Iukhta TV, Gevorgian AG et al. A long-term response to allogeneic hemopoietic stem cell transplantation from haploidentical donor and post-transplant therapy in an adolescent with primary resistant neuroblastoma. Cell Ther Transplant 2020; 9(2): 71-77.

\section{Summary}

Neuroblastoma (NB) is the most frequent pediatric extracranial solid tumor characterized by extreme biological heterogeneity with variable clinical course. Older age is an important risk factor. These patients may lack other common risk features but still have a chemoresistant disease with dismal prognosis. As there is currently no consensus on optimal treatment for patients with primary resistant $\mathrm{NB}$, a number of clinical options is being explored including immunotherapy-based approaches. Immunotherapy with dinutuximab beta (DB) have proven its effectiveness as maintenance therapy. Allogeneic stem cell transplantation from haploidentical donor (haplo-HSCT) may be an effective consolidation in some cases. However, all forms of immunotherapy are much less effective in patients with large residual tumor. While there is no data on immune checkpoints inhibitors effectiveness in NB, some patients may benefit from this option as a part of complex immunotherapy strategy.

\section{Case presentation}

A 12-year old girl with gross paravertebral thoracic and abdominal tumor was diagnosed with undifferentiated neuroblastoma and bone metastases. While there was no response to several lines of chemotherapy, and only partial tumor resection was possible, the hematopoietic stem cell transplantation from haploidentical donor (haplo-HSCT) was performed as salvage therapy. Since there was only minor decrease in tumor volume with good dynamics by MIBG scan, additional post-transplant therapy was initiated. External beam radiotherapy was given for local control. The patient also received combined immunotherapy with DB and nivolumab. Currently, 3.5 years post haplo-HSCT, despite still gross residual tumor mass, it is MIBG-negative and shows signs of differentiation. 


\section{Conclusion}

The combination of haplo-HSCT with post-transplant anti-GD2 and nivolumab may lead to a long-term response in an adolescent with primary resistant $\mathrm{NB}$ in spite of a large residual tumor mass.

\section{Keywords}

Neuroblastoma, pediatric, resistant, hematopoietic transplantation, immunotherapy.

\section{Introduction}

Neuroblastoma (NB) is the most common pediatric extracranial solid tumor. However, while only $7-8 \%$ of children with cancer are diagnosed with $\mathrm{NB}$, it is responsible for about $10 \%$ of cancer-related deaths in this population [1]. As more as $50 \%$ of high-risk group patients still develop a relapse in spite of highly intensive complex therapy used [2]. The patient's age (>18 months), along with biological characteristics (MYCN amplification, 1p deletion, tumor DNA ploidy) and disease stage, is among the factors used to determine a risk group, to which the patient belongs [3]. Also, the age over 5 years at diagnosis is one of the factors used to determine an 'ultra-high' risk subgroup among high-risk patients [4]. Although less than $25 \%$ of high-risk patients are older than 5 years [4], and only 3\% are older than 10 years [5], this group makes a significant input into overall NB-associated mortality [6]. The "adolescent" and "adult" NB cases seem to be different in their biological characteristics from younger cohorts since very few patients have MYCN-driven high-risk tumor [5], though having other biological factors at play [7]. These tumors are often characterized by aggressive local growth with relatively few distant metastases. As they are often resistant to standard chemotherapy regimens, local control measures and other systemic options, such as immunotherapy, play a significant role [8]. The allogeneic hematopoietic stem cell transplantation from haploidentical donor (haplo-HSCT) is an effective option for primary refractory and relapsed NB patients [9] which also may be used as a 'platform' for further immunotherapy [10].

Here we report the results of combined treatment including a haplo-HSCT with subsequent immunotherapy in a 12-year old girl with primary refractory NB.

\section{Case presentation}

In January 2016, a 12-year-old girl was diagnosed with non MYCN-amplified metastatic NB. At the time of diagnosis the patient had pain, fever. The chest and abdominal CT have shown a large paravertebral tumor invading the spinal canal at Th10-L4 level, an abdominal lesion $247 \times 158 \mathrm{~mm}$ in size growing into the psoas muscle. The urethral compression and tumor invasion into left hilum led to left-sided hydronephrosis. There were also lytic lesions in Th3-4 and L3 vertebrae. The paravertebral lesion biopsy was performed and tumor morphology corresponded to undifferentiated neuroblastoma. No MYCN amplification was revealed, $1 \mathrm{p}$ or $11 \mathrm{q}$ chromosome deletions were subsequently found. The serum NSE was 380 ng/ml, LDH 1520 U/l. The tumor was ${ }^{123}$ I-metaiodobenzylguanidine (MIBG)-positive with vivid tracer accumulation in thoracic and abdominal lesions, Th3-4 and L1-4 vertebrae. The therapy according to modified GPOH NB2004 protocol for high-risk patients (6 alternating N5/N6 cycles) was started (Fig. 1). No response was achieved by CT/MRI or MIBG scan. Subsequently, additional 3 topotecan-containing N8 cycles were performed, resulting in only disease stabilization. The surgical intervention was performed, but no local control was achieved, as only partial resection was possible. As the patient was not a candidate for autologous hemopoietic stem transplantation (auto-HSCT) as a poor mobilizer and there was a negative post-surgery dynamics with abdominal tumor growing to $175 \times 131 \mathrm{~mm}$, three additional RIST (rapamycin, irinotecan, sprycel, temozolomide) cycles were performed achieving again just disease stabilization.

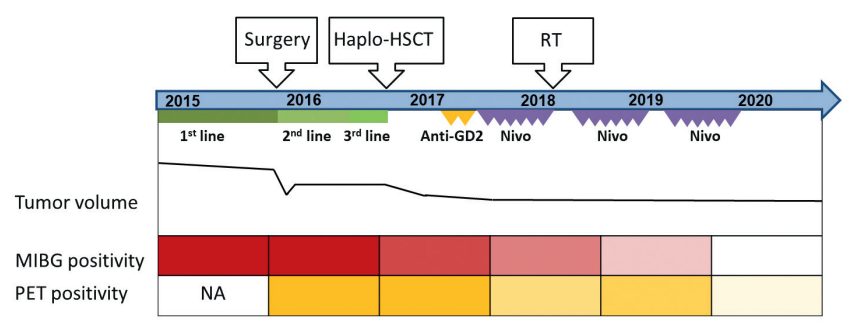

\section{Figure 1. The therapy flow-chart}

As none other clinical options were available, the haploHSCT from KIR-incompatible brother was performed as salvage therapy. Reduced-intensity conditioning regimen (fludarabine $150 \mathrm{mg} / \mathrm{m}^{2}$, melphalan $140 \mathrm{mg} / \mathrm{m}^{2}$ ) was used. The transplant was modified via CliniMACS device (Miltenyi Biotec, Bergisch Gladbach, Germany) to deplete T-cell receptor alpha/beta positive $(\mathrm{TCR} \alpha \beta(+))$ and CD19 positive $(\mathrm{CD} 19(+))$ cells from initial apheresis products. The basic immunosuppression consisted of mycophenolate mofetil from D-1 to D+60 as the patient received a modified transplant. Engraftment was registered on D+12. The early post-transplant period was complicated by Gr2 skin, Gr3 gut and Gr1 hepatic acute graft-versus-host disease (aGvHD) with good response to steroids and extracorporeal photopheresis (ECP). After aGvHD signs emergence, tacrolimus was added on $\mathrm{D}+16$. Also, asymptomatic infection with hepatitis $\mathrm{C}$ virus was found with negative status achieved with subsequent specific therapy. Later on, moderate chronic GvHD was observed (skin involvement in 20\% of BSA with superficial sclerosis). The patient responded to ECP and topical tacrolimus with complete regress of cGvHD signs.

Disease restaging on $\mathrm{D}+120$ have shown a good positive dynamics by MIBG scanning (see Fig. 2), although CT scan did not show any evident dynamics, and there was still a 
bulky abdominal and paravertebral tumor. The FDG-PET scan have shown hypermetabolic (Deauville score of 4 or 5) areas corresponding to I-MIBG positive lesions. No positive dynamics was seen during subsequent restaging on D+180. Therefore, the patient was given post-transplant immunotherapy with two courses of ch14.18/CHO (Dinutuximab beta, a GD2-targeted antibody). During each course, the drug was given at $10 \mathrm{mg} / \mathrm{m}^{2}$ for 10 days without parallel IL-2 infusions due to the risk of GvHD. On standard supportive therapy only mild and controllable pain was observed. Further on, 4 cycles of differentiating therapy (isotretinoin $160 \mathrm{mg} / \mathrm{m}^{2}$ for 14 days with 14 days break) were administered. The subsequent restaging has shown positive dynamics by I-MIBG and FDG-PET scan (see Figs. 1, 2).

As the patient had no signs of GvHD at restaging and there was still a bulky metabolically active tumor, she was scheduled for additional therapy by PD-1 inhibitor nivolumab. A total of 6 nivolumab infusions were performed with starting dose of $0.5 \mathrm{mg} / \mathrm{kg}$ and subsequent doses of $1 \mathrm{mg} / \mathrm{kg}$ due to the history of GvHD. No immune complications were seen.
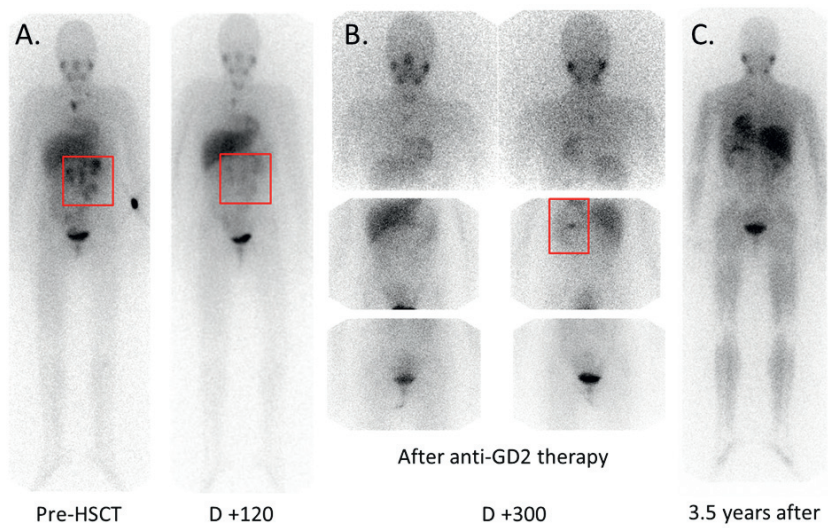

3.5 years after

Figure 2. 123I-MIBG scans prior to haplo-HSCT (A.), after anti-GD2 therapy (B.), and after 3 courses of anti-PD1 therapy (C.)
The restaging on $\mathrm{D}+390$ have shown positive dynamics on I-MIBG scan with more intensive hypermetabolic lesions on FDG-PET scan. The diagnostic tumor biopsy has shown the lesion to consist of large polymorphic cells with signs of gangliocytic differentiation. The patient received 3 additional nivolumab injections with subsequent external beam radiation therapy. The latter involved abdominal tumor (total dose of 37 Gy by 2 Gy fractions; see Fig. 3) and paravertebral lesions irradiated with stereotactic technique (up to total dose of 30 Gy by 6 Gy fractions; see Fig. 3).

The subsequent restaging has shown good positive dynamics by both I-MIBG and PET scans. The patient received 6 more cycles of nivolumab at $1 \mathrm{mg} / \mathrm{kg}$ followed by differentiating therapy (3 cycles, ceased due to skin toxicity). On subsequent restaging there was a positive dynamics by MIBG scam, while FDG-avid lesions were more intensive. After another 6 cycles of nivolumab there are no I-MIBG positive lesions with only residual metabolic activity by FDG-PET scan. No further therapy was given. The patient is currently under observation 3.5 years after haplo-HSCT. No therapy was given for the last 10 months.

\section{Discussion}

Although about $20 \%$ patients with high-risk NB develop primary resistance [11], there is still no consensus on optimal therapy in this group and many patients receive treatment within clinical trials. Among these, the 4 -year event-free survival (EFS) in Phase I-II COG cohort was only $6 \%$ with median time to disease progression of 58 days and $15 \%$-year overall survival (OS) [12]. The meta-analysis of ITCC/SIOPEN trials data on second-line chemotherapy effectiveness in primary resistant and relapsed NB patients yields slightly better results with median EFS of $12.5 \pm 6.8$ months and median OS of $27.9 \pm 20.2$ in primary refractory cohort [13]. However, in our case, the life expectancy was much lower due to a number of highly unfavorable prognostic factors. Beside the age at diagnosis of more than 5 years, highly aggressive
A.
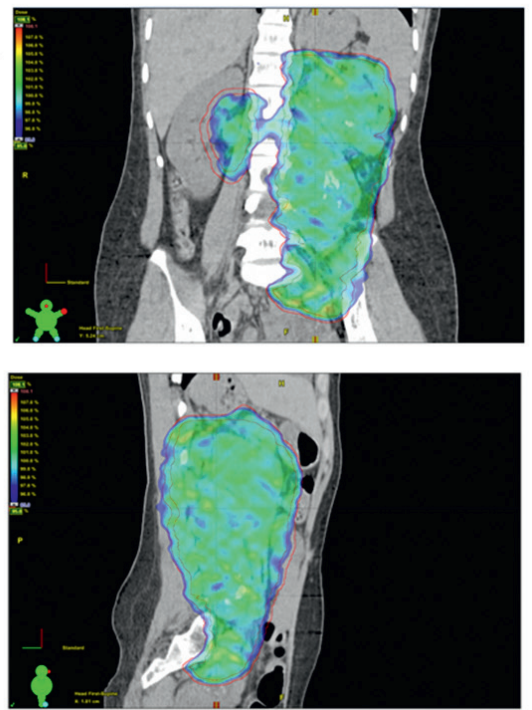

B.
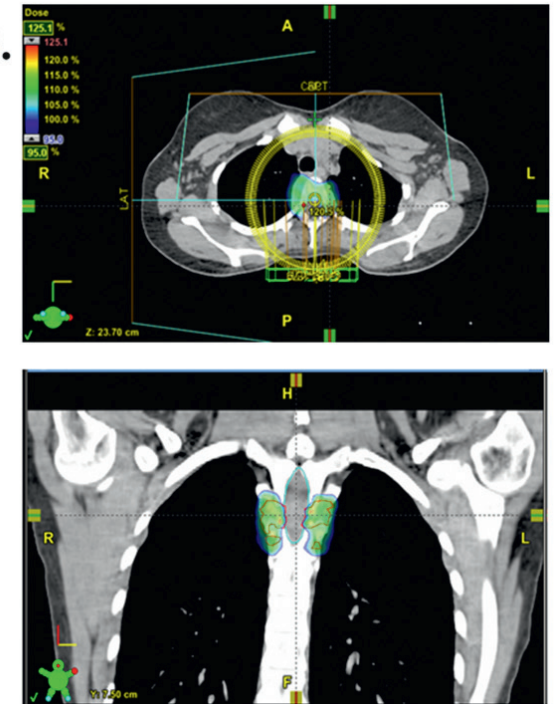

C.
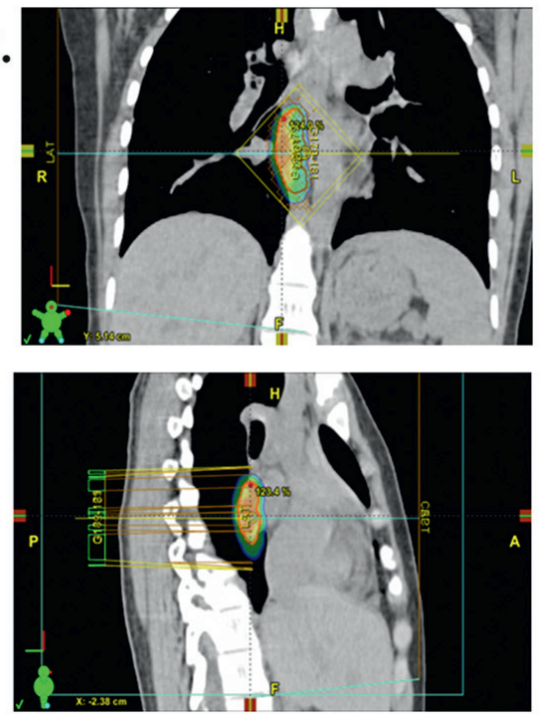

Figure 3. Radiation fields for abdominal (A.) and thoracic (B., C.) residual tumor components 
disease course with distant bone metastases and high initial LDH levels, which are all adverse factors according to risk score by Ladenstein R. et al. [4], there was also no response to first and second-line therapy. While our patient was ineligible for auto-HSCT, in our experience the outcomes in primary resistant patients are dismal even if they respond to $2^{\text {nd }}$ - or $3^{\text {rd }}$-line therapy [14]. The patient described had no response to topotecan-containing N8 therapy and RIST regimen. The latter is effective in some primary resistant cases [15], but not in the case described. Also, the surgical local control, which is extremely important in older patients [8], was unachievable, due to location and extent of the tumor.

The haplo-HSCT is one of the options available as consolidation for patients with primary resistant and relapsed NB. Thus, 5-year EFS and OS in patients receiving CD3 and CD19-depleted graft were $19 \%$ and $23 \%$, accordingly [9]. However, the tumor load prior to haplo-HSCT was one of the most important prognostic factors with overall prognosis still being very poor for patients with significant residual disease. In older patients, however, surgical local control seems to play a decisive role [8], radiation therapy is also effective in most high-risk NB patients with post-surgical residual tumor. While COG ANBL0532 study failed to demonstrate the advantage for dose escalation strategy [16], there is still data suggesting its benefit in patients with gross residual disease [17]. In case described, the total doses of $37 \mathrm{~Gy}$ and $30 \mathrm{~Gy}$ were applied to abdominal and thoracic lesions, accordingly, having been higher than routine dosage used in such cases. However, due to the volume of I-MIBG and FDG-PET positive lesions and history of bone involvement, some additional systemic therapy was viewed as a feasible option.

An anti-GD2 antibody dinutuximab beta is effective as maintenance therapy in high-risk NB patients [18]. It also displayed limited activity as single agent in primary refractory and relapsed patients [19]. It is more effective in combination with irinotecan and temozolomide (1-year EFS of $67.9 \%$ ), although the majority of responders later had some kind of consolidation therapy [20]. This form of immunotherapy also seems to be synergistic with haplo-HSCT. In the cohort of 56 patients with $1^{\text {st }}$ or $\geq 2^{\text {nd }}$ metastatic relapse complete response was seen in $41 \%$ of patients with measurable tumor burden and 3-year OS and EFS were 58\% and 45\%, respectively [10]. However, disease status prior to HSCT was still a major prognostic factor with 3-year EFS in patients with stabilization being only $11 \%$. Therefore, while we achieved good response by I-MIBG scan in our patient, we still considered her a candidate for additional immunotherapy.

Immune checkpoint inhibitors are surprisingly effective in some adults with solid tumors [21], but their use in pediatric cancer patients is much more limited due to fundamental differences in tumor biology between children and adults [22]. Two large pediatric PD-1 inhibitors trials have yielded disappointing results. In KEYNOTE-051 trial, in which a total of $11 \mathrm{NB}$ patients were enrolled, some positive dynamics by I-MIBG scan was achieved only in one patient [23]. In ADVL1412 trial no objective responses were seen in $22 \mathrm{NB}$ patients [24]. However, the latter included mostly patients without PD-L1 expression (1 of 15 samples studied) and some prolonged (6-30 months) disease stabilizations were seen in 4 of 12 patients without large lesions measurable by RECIST. In case reviewed there were some factors in favor of anti-PD1 agents. First, the different disease mechanisms in older patients suggests better neo-antigen expression compared to younger ones [8]. Also, the patient had history of anti-GD2 therapy, which is able to induce PD ligands expression in preclinical models [25]. There are also two case reports demonstrating the synergism of anti-GD2 and anti-PD1 therapy [26]. The PD-1 blocking strategy also seems to be synergistic with allogeneic transplant [27], although the risk of life-threatening GvHD is the main concern in these patients [28]. Although we have generally positive experience in post-transplant use of nivolumab in our clinic [29], we still started from smaller nivolumab doses as this approach proved its effectiveness in lymphoma patients [30].

Although our patient still has gross measurable disease by $\mathrm{CT} / \mathrm{MR}$ imaging, the residual tumor is not accumulating MIBG and shows a marked decrease in glucose metabolism. In some auto-HSCT recipients the MIBG-positive lesion with gradually decreasing MIBG accumulation may be a sign of tumor differentiation [31]. We also had a similar experience in haplo-HSCT recipient, who now maintains a response for more than 100 months post-transplant [32].

\section{Conclusion}

A combination of haplo-HSCT with post-transplant antiGD2 antibody and nivolumab led to a long-term response in an adolescent with primary resistant NB in spite of a large residual tumor mass.

\section{Acknowledgements}

We are much appreciated to Dr. Andrew P. Litvinov for supporting MIBG images and to Dr. Elena Babenko for performing the MACS selection.

\section{Conflict of interests}

None declared.

\section{References}

1. Smith MA, Alterkruse SF, Adamson PC, Reaman GH, Seibel NL. Declining childhood and adolescent cancer mortality. Cancer 2014; 120(16): 2497-2506.

2. Berthold F, Spix C, Katsch P, Lampert F. Incidence, survival, and treatment of localized and metastatic neuroblastoma in Germany 1979-2015. Paediatr Drugs 2017; 19(6): 577-593.

3. Cohn SL, Pearson ADJ, London WB, Monclair T, Ambros PF, Brodeur GM et al. The International Neuroblastoma Risk Group (INRG) Classification System: An INRG Task Force Report. J Clin Oncol. 2009; 27(2): 289-297.

4. Morgenstern DA, Pötschger U, Moreno L, Papadakis V, Owens C, Ash S et al. Risk stratification of high-risk metastatic neuroblastoma: A report from the HR-NBL-1/SIOPEN study. Pediatr Blood Cancer 2018; 65(11): e27363. 
5. Mossé YP, Deyel RJ, Berthold F, Ambros PF, Monclair $\mathrm{T}$ et al. Neuroblastoma in older children, adolescents and young adults: a report from the International Neuroblastoma Risk Group project. Pediatr Blood Cancer. 2014; 61(4): 627-635.

6. Shinagawa T, Kitamura T, Katanoda K, Matsuda T, Ito Y, Sobue T. The incidence and mortality rates of neuroblastoma cases before and after the cessation of the mass screening program in Japan: A Descriptive Study. Int J Cancer. 2017; 140(3): 618-625.

7. Hertwig F, Peifer M, Fischer M. Telomere maintenance is pivotal for high-risk neuroblastoma. Cell Cycle. 2016; 15(3): 311-312.

8. Suzuki M, Kushner BH, Kramer K, Basu EM, Roberts SS, Hammond WJ et al. Treatment and outcome of adult-onset neuroblastoma. Int J Cancer 2018; 143(5): 1249-1258.

9. Illhardt T, Toporski J, Feuchtinger T, Turkiewicz D, Teltschik HM, Ebinger $\mathrm{M}$ et al. Haploidentical stem cell transplantation for refractory/relapsed neuroblastoma. Biol Blood Marrow Transplant 2018; 24(5): 1005-1012.

10. Lang P, Flaadt T, Ebinger M, Schlegel P, Lode H, Ladenstein $\mathrm{R}$ et al. Haploidentical stem cell transplantation and subsequent immunotherapy with antiGD2 antibody for patients with relapsed metastatic neuroblastoma. Clin Cancer Res 2019; 7(2_s): Abstract A013.

11. Matthay KK, Reynolds CP, Seeger RC, Shimada H, Adkins ES, Haas-Kogan D et al. Long-term results for children with high-risk neuroblastoma treated on a randomized trial of myeloablative therapy followed by 13 -cis-retinoic acid: a children's oncology group study. J Clin Oncol 2009; 27(7): 1007-1013.

12. London WB, Bagatell R, Weigel BJ, Fox E, Guo D, Van Ryn $\mathrm{C}$ et al. Historical time to disease progression and progression-free survival in patients with recurrent/refractory neuroblastoma treated in the modern era on Children's Oncology Group early-phase trials. Cancer 2017; 123(24): 49144923.

13. Moreno L, Rubie H, Varo A, Le Deley MC, Amoroso L, Chevance A et al. Outcome of children with relapsed or refractory neuroblastoma: A meta-analysis of ITCC/SIOPEN European phase II clinical trials. Pediatr Blood Cancer 2017; 64(1): 25-31.

14. Kazantsev IV, Gevorgyan AG, Yukhta TV, Tolkunova PS, Kozlov AV, Andreeva TV et al. High-dose chemotherapy with autologous hematopoietic stem cell transplantation in high-risk neuroblastoma patients: R. Gorbacheva Memorial Research Institute of Children Oncology, Hematology and Transplantation, First Pavlov State Medical University of St. Petersburg experience. Russian Journal of Pediatric Hematology and Oncology. 2018; 5(4): 11-20. (In Russian).

15. Indolfi P, Corbacioglu S, Perrotta S, Rossi F, Marte A, Pota E et al. Targeted molecular therapy (modified RIST regimen) in relapsed high risk stage IV neuroblastoma: two cases report. Theory Clin Pract Pediatr. 2018; 2(1): 1-3.
16. Liu KX, Naranjo A, Zhang FF, Dubois SG, Braunstein SE, Voss SD et al. Role of radiotherapy dose-escalation for highrisk neuroblastoma with post-surgical primary site gross residual disease: A report from the COG ANBL0532 Study. Int J Radiat Oncol Biol Phys. 2019; 105(1s): S3.

17. Casey DL, Kushner BH, Cheung NKV, Modak S, LaQuaglia MP, Wolden SL. Dose-escalation is needed for gross disease in high-risk neuroblastoma. Pediatr Blood Cancer. 2018; 65(7): e27009.

18. Ladenstein R, Pötschger U, Valteau-Couanet D, Luksch $\mathrm{R}$, Castel V, Ash S et al. Investigations of the role of dinutuximab beta-based immunotherapy in the SIOPEN High-Risk Neuroblastoma 1 Trial (HR-NBL1). Cancers. 2020; 12(2): 309.

19. Mueller I, Ehlert K, Endres S, Pill L, Siebert N, Kietz S et al. Tolerability, response and outcome of high-risk neuroblastoma patients treated with long-term infusion of anti-GD2 antibody ch14.18/CHO. MAbs 2018; 10(1): 55-61.

20. Mody R, Yu AL, Naranjo A, Zhang FF, London WB, Shulkin BL et al. Irinotecan, temozolomide, and dinutuximab with GM-CSF in children with refractory or relapsed neuroblastoma: A report from the Children's Oncology Group. J Clin Oncol. 2020: JCO2000203. [Epub ahead of print].

21. Herrscher H, Robert C. Immune checkpoint inhibitors in the metastatic, neoadjuvant, and adjuvant settings. Curr Opin Oncol. 2020; 32(2): 106-113.

22. Gröbner SN, Worst BC, Weischenfeldt J, Buchhalter I. Kleinheinz K, Rudneva VA et al. The landscape of genomic alterations across childhood cancers. Nature 2018; 555(7696): 321-327.

23. Geoerger B, Kang HG, Yalon-Oren M, Marshall LV, Vezina C, Pappo A et al. Pembrolizumab in paediatric patients with advanced melanoma or a PD-L1-positive, advanced, relapsed, or refractory solid tumour or lymphoma (KEYNOTE-051): Interim analysis of an open-label, single-arm, Phase 1-2 trial. Lancet Oncol. 2020;21(1): 121-133.

24. Davis KL, Fox E, Merchant MS, Reid JM, Kudgus RA, Xiaowei L et al. Nivolumab in children and young adults with relapsed or refractory solid tumours or lymphoma (ADVL1412): A multicentre, open-label, single-arm, Phase 1-2 trial. Lancet Oncol. 2020;21(4): 541-550.

25. Ehlert K, Hansjuergens I, Zinke A, Sylke O, Siebert N, Henze $G$ et al. Nivolumab and dinutuximab beta in two patients with refractory neuroblastoma. J Immunother Cancer. 2020;8(1): e000540.

26. Siebert N, Zumpe M, Jüttner $M$, Troschke-Meurer S, Lode HN. PD-1 blockade augments anti-neuroblastoma immune response induced by anti-GD2 antibody ch14.18/ CHO. Oncoimmunology. 2017; 6(10): e1343775.

27. Soiffer RJ. Checkpoint inhibition to prevent or treat relapse in allogeneic hematopoietic cell transplantation. Bone Marrow Transplant. 2019;54(Suppl 2):798-802. 
28. Ijaz A, Khan AY, Malik SU, Faridi W, Fraz MA, Usman $\mathrm{M}$ et al. Significant risk of graft-versus-host disease with exposure to checkpoint inhibitors before and after allogeneic transplantation. Biol Blood Marrow Transplant 2019; 25(1): 94-99.

29. Lepik KV, Kozlov AV, Borzenkova ES, Popova MO, Moiseev IS, Darskaya EI. Safety and efficacy of nivolumab applied at different dosage in the patients with relapsing Hodgkin lymphoma after allogeneic hematopoietic stem cell transplantation. Cell Ther Transplant. 2018; 7(2): 28-35.

30. Fedorova LV, Lepik KV, Mikhailova NB, Kondakova EV, Zalyalov YuR, Beynarovich AV et al. Interim analysis of effectiveness and safety of Nivolumab $40 \mathrm{mg}$ in relapsed/refractory Hodgkin lymphoma. Cell Ther Transplant. 2018; 7(3): 53-54.

31. Okamoto Y, Kodama Y, Nishikawa T, Rindiarti A, Tanabe T, Nakagawa $S$ et al. Persistent positive metaiodobenzylguanidine scans after autologous peripheral blood stem cell transplantation may indicate maturation of stage 4 neuroblastoma. Pediatr Hematol Oncol. 2017;34(3):157-164.

32. Tolkunova PS, Kazantsev IV, Gevorgyan AG, Youkhta TV, Kozlov AV, Morozova EV et al. Long-term disease stabilization in a patient with relapsed neuroblastoma after allogeneic hematopoietic stem cell transplantation. Clinical case and literature review. Russian Journal of Pediatric Hematology and Oncology. 2018; 5(1): 68-72. (In Russian). 


\title{
Долгосрочный ответ на аллогенную трансплантацию гемопоэтических стволовых клеток от гаплоидентич- ного донора и посттрансплантационную терапию у подростка с первично-резистентной нейробластомой
}

\author{
Илья В. Казанцев ${ }^{1}$, Татьяна В. Юхта ${ }^{1}$, Асмик Г. Геворгян ${ }^{1}$, Полина С. Толкунова ${ }^{1}$, Андрей В. Шамин ${ }^{2}$, \\ Вадим В. Байков ${ }^{3}$, Николай А. Воробьев ${ }^{4}$, Андрей В. Козлов ${ }^{1}$, Марина А. Карзакова ${ }^{2}$, Полина С. Куга ${ }^{1}$, \\ Александр Н. Швецов ${ }^{1}$, Елена В. Морозова ${ }^{1}$, Светлана С. Сафонова ${ }^{1}$, Юрий А. Пунанов ${ }^{1}$, \\ Людмила С. Зубаровская ${ }^{1}$, Борис В. Афанасьев ${ }^{1}$ \\ ${ }^{1}$ НИИ детской онкологии, гематологии и трансплантологии им. Р. М. Горбачевой, Первый Санкт-Петербургский \\ государственный медицинский университет им. акад. И. П. Павлова, Санкт-Петербург, Россия \\ ${ }^{2}$ Самарская областная детская больница им. Н. Ивановой, Самара, Россия \\ ${ }^{3}$ Кафедра патологической анатомии, Первый Санкт-Петербургский государственный медицинский университет \\ им. И. Павлова, Санкт-Петербург, Россия \\ ${ }^{4}$ Медицинский институт им. Березина, Санкт-Петербург, Россия; Северо-Западный государственный медицинский \\ университет им. И. Мечникова; Санкт-Петербургский государственный университет, Санкт-Петербург, Россия \\ ${ }^{5}$ Отдел и кафедра рентгенологии, Первый Санкт-Петербургский государственный медицинский университет \\ им. И. Павлова, Санкт-Петербург, Россия
}

\section{Резюме}

Нейробластома (НБ) является наиболее частой экстракраниальной опухолью у детей. Она характеризуется чрезвычайной биологической гетерогенностью с вариабельным клиническим течением. Старший возраст является важным фактором риска. У этих пациентов могут отсутствовать другие частые факторы риска, но у них, тем не менее, развивается хеморезистентное заболевание с плохим прогнозом. Поскольку сейчас нет консенсуса по оптимальному лечению пациентов с первично-резистентной НБ, для них исследуют различные клинические опции, включая иммунотерапевтические подходы. Иммунотерапия динутуксимабом бета (ДБ) показала свою эффективность в качестве поддерживающей терапии. Аллогенная трансплантация гемопоэтических стволовых клеток (алло-ТГСК) от гаплоидентичного донора может быть эффективной консолидирующей терапией в некоторых случаях. Однако все виды иммунотерапии намного менее эффективны у пациентов с большой остаточной опухолью. Поскольку нет данных об эффективности ингибиторов иммунных контрольных точек при НБ, некоторые пациенты могут выиграть от этого варианта лечения, как части комплексной иммунотерапии.

\section{Описание клинического случая}

У 12-летней девочки была диагностирована большая паравертебральная опухоль в грудной и абдоминальной области с костными метастазами. Поскольку вначале не было ответа на несколько линий химиотерапии и была возможна только частичная резекция опухоли, была проведена ТГСК от гапло- идентичного донора в качестве терапии спасения. Так как было отмечено только минимальное снижение объема опухоли с хорошей динамикой при MIBG-сканировании, то была начата дополнительная посттрансплантационная терапия. Для локального контроля была назначена лучевая терапия на опухоль. Пациентка получала также комбинированную иммунотерапию препаратом ДБ и ниволумабом. В настоящее время, через 3,5 года после гапло-ТГСК, несмотря на значительную остаточную опухоль, она остается MIBG-отрицательная и имеет признаки дифференцировки.

\section{Выводы}

Сочетание гапло-ТГСК с назначением антител к гликолипиду GD2 и ниволумаба может вести к долговременному ответу у подростка с первично-резистентной НБ, несмотря на большую остаточную опухолевую массу.

\section{Ключевые слова}

Нейробластома, детский возраст, резистентная, трансплантация гемопоэтических клеток, иммунотерапия. 